4. Collins, Wilkie. The Moonstone. 1868. Ed. Sandra Kemp. New York: Penguin, 1999.

5. Eco, Umberto. «Narrative Structures in Fleming.» The Role of the Reader: Evidence in England. Baltimore: Johns Hopkins University Press, 1992.

6. Miller, D.A. The Novel and the Police. Los Angeles: University of California Press, 1988, pp 222

7. Peterson, Audrey. Victorian Masters of Mystery: From Wilkie Collins to Conan Doyle. New York: Frederick Ungar, 1984.

8. Thoms, Peter. Detection and Its Designs: Narrative and Power in $19^{\text {th }}$-century Detective Fiction. Athens, Ohio: Ohio University Press, 1998. P. 44-65

9. Todorov, Tzvetan. The Typology of Detective Fiction. The Poetics of Prose. Trans. Richard Howard. Ithaca: Cornell University Press, 1977.

DOI https://doi.org/10.30525/978-9934-26-039-1-59

\title{
ОСОБЛИВОСТІ ПОЕЗІЇ М. ВІНГРАНОВСЬКОГО (ТРОПИ, ПОЕТИЧНИЙ СИНТАКСИС, ФОНІКА)
}

\author{
Погребенник І. Л. \\ кандидат філологічних наук, \\ викладач української мови і літератури \\ Чернівеиького вищого комериійного училища
}

Київського національного торговельно-економічного університету м. Чернівиі, Україна

М.Вінграновський - один із найвідоміших українських поетів XX ст., чия творчість набуває все більшого суспільного значення. Окремі елементи поетики творів М.Вінграновського досліджували А. Макарів, М. Ільницький, . Дзюба, Ю. Ковалів, Т. Салига, Ю. Сердюк, В. Моренець, І.Гришин-Грищук, Л.Талалай, Р.Дідула, Л. Старовойт. Однак спеціального системного дослідження поетики віршованих творів М. Вінграновського у діахронії досі немає, що й обумовлює актуальність теми.

Найчастіше у поетичній творчості М.Вінграновський звертається до порівняння та всіх його видів. Серед простих переважають індивідуально-авторські: «Як танський фарфор - все минає: Корою, снігом, рукавом...» [5, с. 5]. До розгорнутих порівнянь, або ж 
однорідних, належать дві строфи вірша «Канни»: «Наче вони не канни -/ Квіти червоноброві,/ Наче з моєї крові/ Мною загублені рани:// Наче до мене в жили/ Прагнуть упитись кров'ю,/ Наче вони не дожили/ Зненавистю й любов’ю» [5, с. 7]. До загальновживаних порівнянь можемо віднести такі: «де, мов живі, до ранку йшли кущі» («Червоною задумливою лінією...»), «збігалися, немов чорти, чи відьми» («Червоною..»), «з великими, як зненависть очима» («Ми підійшли»). Натомість «І світ, і Всесвіт, повний таємниці» [5, с. 11] - зразок безсполучникового порівняння за допомогою предиката.

Також М. Вінграновський широко використовує епітети. Зауважимо, автор оперує у своїй творчості багатьма видами епітетів, але найбільш вживаний у нього прикметник. Наприклад, «синій сон у небесному морі», «на всесвітнім святковім чолі», «зорі німі» («Синій сон»), «зором своїм червоним», «червоні чайки», «сонячні чайки» («Канни»). Цікавим є вірш «Червоною задумливою лінією», перші рядки якого побудовані на епітетах: «Червоною задумливою лінією/ У сизих вербах, в голубій імлі/ В тонкій руці 3 прив'яленою лінією/ Окреслилась ти на вечірнім тлі» [5, с. 23]. Часто епітети фігурують у назвах віршів: «Чорна райдуга», «Синій сон у небесному морі», «Стоять сухі кукурудзи», «Під рябими кущами вухатими», «Сива стомлена сутінь снігів», «Новорічна заяча пісня» та інші. Епітет «хмаринка-мама» [5, с. 37], що є прикладом іменникового художнього означення, можна вважати неповторною знахідкою поета. Сюди ж зараховуємо: «світні-сміховинні», «якийсь дідок-перестрибок», «при зимі-весні-осені». Особливою майстерністю відзначаються епітети різних видів, об'єднані єдиним метафоричним контекстом за допомогою відразу двох дефісів: «в черночо-чорно-чорний час»; одного дефісу: «тихо-тихими губами», «а тінь тремтливополохлива», «...матово-темнавими вночі».

Синонімом до творчого образного мислення можна вважати метафоричне мислення. Саме завдяки такому мисленню творились вірші М. Вінграновського. У його поезіях метафорою пройняті не лише цілі строфи, а й окремі вірші. При цьому поет використовує й інші художні засоби. Наприклад, у вірші «Синій сон у небесному морі» кожен рядок першої строфи побудований на метафорі, але всі разом вони творять образ космічного спокою. У наступній строфі нова метафора - «Спить жадання якесь таємниче/ На всесвітнім святковім чолі» - продовжує розвивати тему «сну у небесному морі». Сон супроводжується тишею, тому читаємо далі: «тиша тишу по імені кличе». Із кожним новим тропом (метафорою), який змістовно поєднується 3 ідеєю всього вірша, розкривається образ сюрреалістичної дійсності: «..Пахне пилом і потом Землі. / Пахне сіном у Чумацькому Возу,/ Що мені сивиною сія, / 16 
I тремтить яс стебло верболозу,/ Зачарована мрія моя...» [5, с. 6]. Думка ліричного героя обривається: зображення дійсності може мати свій несподіваний кінець, але ліричний герой дозволяє нам помріяти, а сам повертається у світ почуттів.

Поезії «Романс», «Плач Ярославни», «До нас прийшов лелека» також $\epsilon$ зразком вмілого використання М. Вінграновським метафор. Лелека 3 твору «До нас прийшов лелека...» набуває рис образу смерті: «До нас прийшов лелека/ 3 косою на плечі/ Води напився з глека/ Тай сів на спориші» [5, с. 29]. Поняття смерті поет «спростовує» іншим поняттям, зокрема вічності. Завершення вірша персоніфікацією «І плакав наш лелека/ 3 косою на плечі» підводить нас до розуміння того, чому ж ллються сльози під час вічної розлуки.

Яскраву образність і змістове наповнення метафор простежуємо як на початку творчості поета, так і в останніх віршах М. Вінграновського. Наприклад, у вірші «Ви як стежка, кохана...» (1955) кожна метафора $\epsilon$ новотвором поета: «лине сон мій по вашій стежині», «з неба падають зорі в дзьоби журавлів» [4, с. 17].

У М.Вінграновського зустрічаються цікаві та незвичні приклади уособлення як виду метафори («димно дихають у сивих снігах сосеняточка і сосенята», «ліщина дивиться горіхами на хмару», «наш чорний вус у чорний гнів тече», «і юний меч наш розгинав спину», «руїна захлинається руїною», «народ вже тереном зацвів», «сірий дощик скаче в казані» тощо).

Спорідненим із метафорою тропом є метонімія, що полягає в заміні одного слова іншим на основі суміжності ознак. У М.Вінграновського метонімія трапляється рідко, і переважно виражена такими видами: називання абстрактного поняття за допомогою конкретного: «і серце вже оточують старці»; ознака суб'єкту замість об'єкту: «колесо котить себе»; називання ознаки людини замість ознаки стихії: «ми знаєм крики наших вод»; називання місця помешкання чи перебування людей замість самих мешканців: «ми на Вкраїні хворі Україною». Кількісна метонімія або синекдоха у творчості поета теж доволі рідкісне явище. Знаходимо такі зразки синекдохи як заміну частини цілим: «ти виглядаєш іншого вже літа»; видове означення замість родового: «ми проживем 3 тобою й на картоплі...».

Різноманітною та багатою $є$ творчість М. Вінграновського з погляду синтаксису. Анафора - одна з найбільш уживаних стилістичних фігур зустрічається в останній строфі вірша «Не руш мене. Я сам самую»: «Не - відбувалось. Не - тремтіло./ Не - золотіло. Не - текло./ Не полотніло. Не - біліло./ Не... - Господи! - не - не було!..» [5, с. 6]. 
Особливою анафоричністю відзначається вірш «Вона була задумлива, як сад». Вираз «вона була» повторюється дванадцять разів. Таке кількаразове повторення в ритмічній синтаксичній групі (строфі) ми називаємо епігоном. Інша анафора - «непевний кроче мій» $-\epsilon$ основою п’ятої строфи: «Непевний кроче мій, іди!/ Непевний кроче мій, іди!! Непевний кроче мій, іди!!!/ Непевний кроче мій, не йди...» [5, с. 12].

У поетичному синтаксисі М.Вінграновського фіксуємо також повтор однокореневих слів 3 нетотожними сучасними значеннями і схожим звучанням, етимологізацію: «Ходить ніч твоя, ходить ніч моя/ Їм не велено ночувати./ Коло кола ти, коло кола я - Велим-велено начувати» $[10$, с. 273]. Трапляються також випадки використання тавтології 3 художньою метою. Так, М.Вінграновський, пародіюючи канцелярськоділовий стиль, де не вживають слова «справді», а тільки кальку 3 російської - «дійсно», ось так відкидав звинувачення: «Я формаліст. Я наплював на зміст/ Відповідаю фігурально:/ Якщо народ мій числиться формально,/ Тоді я дійсно формаліст» [10, с. 276].

У творчості поета знаходимо також яскраві приклади градації, зокрема: «Вже хмари омивають мої плечі,/ Уже в самому небі я стою. / Уже по груди в небі, вже по пояс,/ Вже Україну видно мені всю,/ І світ, і Всесвіт, повний таємниці...» [10, с. 281].

Вірші М. Вінграновського доволі мелодійні, ритмічні, повторюючи різні приголосні та голосні звуки, поет створює нові образи. Наведемо приклад алітерації: «Сива стомлена сутінь снігів,/ Слід сорочий і лисячий слід,/ I під крилами хмар-снігурів/ Сонця зимнього жевріє глід.» [5, с. 63] Алітерація витримана протягом усього вірша, завдяки чому автор розгортає перед читачем картину зимового пейзажу та «сонливих відчуттів». На противагу алітерації, асонанс ю-у-і-ї створює мелодику ніжності й любові: «Люблю й, сумуючи, ловлю/ I ясні зорі, й тихі води,/ Люблю свободу, звук свободи./ Але її одну люблю...» [5, с. 73].

Отже, у поетичній творчості М. Вінграновського фіксуємо найрізноманітніші художні засоби. Поет вдається до всіх видів порівнянь, проте перевагу надає індивідуально-авторським. Важливу роль у його поезії відіграє епітет, а найбільш вживаним є прикметник. Мова творів образна, метафорична. Натомість метонімія й синекдоха зустрічаються вкрай рідко. Різноманітною і багатою $є$ синтаксична організація поезій, представлена майже всіма класичними фігурами. Також знаходимо приклади етимологізації. Усе це свідчить про мелодійність і ритмічність як основні якісні характеристики доробку М.Вінграновського. 


\title{
Література:
}

1. Вінграновський М. С. Атомні прелюдии: поезії / вступ. ст. Б. Буряка. Київ: Рад. письменник, 1962.118 с.

2. Вінграновський М. С. На срібнім березі: поезії. Київ: Молодь, 1978. $78 \mathrm{c}$.

3. Вінграновський М. С. Київ: поезії. Київ: Дніпро, 1982. 156 с.

4. Вінграновський М. С. Цю жінку я люблю: лірика. Київ: Дніпро, 1990. 206 c.

5. Вінграновський М. С. Любове, ні! не прощавай!: вибр. лірика. Київ: Укр. письменник, 1996. 149 с.

6. Дідула Р. Він гранив слово рідне : творчий спадок М. Вінграновського. Літ. Україна. 2006. 23 берез. С. 1-7.

7. Салига Т. М. Вінграновський. Київ: Рад. письменник, 1989. 156 с.

8. Старовойт Л. Мотиви і образи лірики Миколи Вінграновського. Питання літературознавства. Чернівці: Рута, 2007. Вип. 74. С. 74-81.

9. Талалай Л. Ілюзія добра і щастя : роздуми над поезією Миколи Вінграновського. Березіль. 2004. № 7-8. С. 166-176.

10. Ткаченко А. Мистецтво слова. Вступ до літературознавства. Київ: Правда Ярославичів, 1998. 448 с.

DOI https://doi.org/10.30525/978-9934-26-039-1-60

\section{ЕКЗИСТЕНЦІЙНА САМОТНІСТЬ АДРЕСАНТА В ЕПІСТОЛЯРІЇ ВІНСТОНА ЧЕРЧИЛЛЯ}

\author{
Семенюк О. Б. \\ старший викладач кафедри романо-германських мов \\ Національної академії Служби безпеки України \\ м. Київ, Украӥна
}

Проблема екзистенційної самотності генія неодноразово досліджувалася у літературознавчих студіях (Н. Хамітов І. Денисюк, М. Ільницький, Н. Калениченко, О. Кривуляк, Колінько О. П.). Проте спосіб зображення самотності людини як ознаки людської екзистенції через призму вираження внутрішнього світу митця в епістолярній формі ще не достатньо вивчена.

Розмірковуючи над явищем самотності, екзистенціалісти намагалися довести, що єдиний засіб звільнення від самотності - це заглиблення в себе, у сутність свого буття і внутрішній світ людини. Дослідник 